\title{
Substance Use Never Current Former
}

National Cancer Institute

\section{Source}

National Cancer Institute. Substance Use Never Current Former. NCI Thesaurus. Code C83003.

An indication or description that an individual's substance usage status is never, current, or former. 